\title{
Milk from different species on physicochemical and microstructural yoghurt properties
}

\author{
Felipe Santana Vianna ${ }^{1}$ Anna Carolina Vilhena da Cruz Silva Canto ${ }^{1}$ Bruno Costa-Lima $^{1}$ iD \\ Ana Paula Salim ${ }^{1}$ (D) Celso Fasura Balthazar ${ }^{1}$ Marion Pereira Costa $^{1}$ (D) Pedro Panzenhagen ${ }^{1}$ (iD \\ Rachel Rachid ${ }^{3}$ Robson Maia Franco $^{1}$ (D) Carlos Adam Conte-Junior ${ }^{12^{*}}$ (D) \\ Adriana Cristina de Oliveira Silva ${ }^{1}$ (D)
}

${ }^{1}$ Departamento de Tecnologia de Alimentos, Faculdade de Veterinária, Universidade Federal Fluminense (UFF), Niterói, RJ, Brasil. ${ }^{2}$ Programa de Pós-graduação em Ciência de Alimentos, Instituto de Química, Universidade Federal do Rio de Janeiro (UFRJ), 21949-900, Rio de Janeiro, RJ, Brasil. E-mail: carlosconte@id.uff.br. "Corresponding author.

${ }^{3}$ Centro de Ciências da Saúde, Instituto de Biofísica Carlos Chagas Filho, Universidade Federal do Rio de Janeiro (UFRJ), Rio de Janeiro, RJ, Brasil.

ABSTRACT: The aim of the present research was to evaluate differences in chemical properties and physical structure of yoghurt produced with milk from different species (sheep, cow, and goat). For each trial, whole raw sheep (S), cow (C), and goat (G) milk were used to manufacture $4 L$ of yoghurts $(Y)$ from each species ( $S Y, C Y$, and $G Y$, respectively). The $S Y$ demonstrated the greatest $(P<0.05)$ values of total solids, protein, and lipid contents, reflecting on greater $(P<0.05)$ firmness, apparent viscosity and water-holding capacity, and lower $(P<0.05)$ syneresis index than $C Y$ and GY. Consequently, SY exhibited a more compact microstructure and homogeneous matrix with fewer pores. Furthermore, $C Y$ and GY microstructure contained a greater number of pores, which exhibited greater size heterogeneity than SY. Therefore, based on the evaluated physicochemical and microstructural properties of yoghurt, SY demonstrated the most desirable parameter values for dairy industry representing an alternative substitution for cow's milk yogurt.

Key words: fermented products, texture, microstructure, sheep milk, goat milk.

Influência do leite de diferentes espécies nas propriedades físico-químicas e micro estruturais do iogurte

RESUMO: O objetivo da presente pesquisa foi avaliar as diferenças nas propriedades químicas e na estrutura física do iogurte produzido com leite de diferentes espécies (ovinos, bovinos e caprinos). Para cada experimento, leite de ovelha cru (S), vaca (C) e cabra (G), foram usados para fabricar $4 L$ de iogurtes $(Y)$ de cada espécie (SY, CY e GY, respectivamente). O SY demonstrou os maiores (P<0,05) valores de sólidos totais, proteína e conteúdo lipídico, refletindo em maior $(P<0,05)$ firmeza, viscosidade aparente e capacidade de retenção de água e menor $(P<0,05)$ indice de sinérese do que CY e GY. Consequentemente, o SY exibiu uma microestrutura mais compacta e uma matriz homogênea com menos poros. Além disso, a microestrutura CY e GY continha um maior número de poros, que exibiam maior heterogeneidade de tamanho do que o SY. Portanto, com base nas propriedades físico-químicas e micro estruturais avaliadas do iogurte, o SY demonstrou os valores de parâmetros mais desejáveis para a indústria de laticínios, representando uma alternativa de produto adequada aos iogurtes à base de leite de vaca.

Palavras-chave: leite fermentado, textura, microestrutura, leite de ovelha, leite de cabra.

\section{INTRODUCTION}

Yoghurt represents a great source of health-promoting substances due to high levels of viable lactic acid bacteria content, which compete with several opportunistic microorganisms and provide desirable metabolites (MCKINLEY, 2005; IRKIN \& VAPUR EREN, 2008; ERKAYA \& ŞENGÜL, 2012; SETTACHAIMONGKON et al., 2014; COSTA et al., 2015a; COSTA et al., 2017) that contribute to consumer health and the development of yoghurt aroma and flavour (CHENG, 2010). Yoghurt can be produced utilizing milk from different species (TAMIME \& ROBINSON, 2007). Furthermore, yoghurt characteristics such as convenience, price and flavour are important attributes determinant to consumer final product acceptability (POHJANHEIMO \& SANDELL, 2009; COSTA et al., 2017).

Previous studies in dairy science commonly utilized cow milk potentially due to their large volume and economic importance (AL-SHERAJI 
et al., 2012; MAYER et al., 2012; LEE et al., 2013; WEN et al., 2014; ZHANG et al., 2014). Nonetheless, in many countries specific climatic and geographical features favor dairy goat and sheep farming, making such activity essential for the national and regional economy (PANDYA \& GHODKE, 2007; PARK et al., 2007). In addition, goat milk products have essential characteristics for human nutrition as higher digestibility (small fat globules) and less allergenicity (low $\alpha_{s 1}$-casein content) (UYSAL-PALA et al., 2006). Moreover, sheep milk products have high nutritive and organoleptic traits due to greater contents of proteins, linolenic acid, essential amino acids, vitamins, and minerals when compared to cow milk products (KAMINARIDES et al., 2007; PARK et al., 2007). Furthermore, previous studies have demonstrated that the aforementioned milks can be used for the production of fermented dairy products (KATSIARI et al., 2002; PAPADIMITRIOU et al., 2007; SANAL et al., 2011; ŞENEL et al., 2011; DE RENOBALES et al., 2012; DOMAGAŁA et al., 2013; SILVA et al., 2017; VIEIRA et al., 2017).

Yoghurt microstructure is composed by a protein network of casein micelle aggregates entrapping fat globules and serum which directly influences this type of fermented product texture (HERRERO \& REQUENA, 2006; NGUYEN et al., 2015). This yoghurt microstructure and textural properties are directly associated with desirable functional and sensory parameters (LEE \& LUCEY, 2003; RAO \& SILVA, 2007). In addition, previous studies have documented relation between yoghurt textural properties and microstructure (DOMAGAŁA, 2009; WANG et al., 2012; NGUYEN et al., 2014a; NGUYEN et al., 2014b; YANG et al., 2014; NGUYEN et al., 2015). Electron scanning microscopy is a reliable tool to visualize yoghurt structure facilitating the characterization of protein chains, microorganisms, fat globules, carbohydrates, and clusters (NAKTHONG, 2012). Moreover, differences in physicochemical characteristics among milk from different species (PARK et al., 2007) directly influence yoghurt textural properties (SHAKEEL HANIF et al., 2012). These properties represent important sensory parameters for product acceptability (COSTA et al., 2016a). Thus, typical defects in yoghurts as low viscosity, reduced firmness (TAMIME \& ROBINSON, 2007), and high level of syneresis can lead to consumer product rejection (AMATAYAKUL et al., 2006). In this context, the present study aimed to compare chemical, textural and microstructural properties of yoghurts produced utilizing sheep, cow and goat milk.

\section{MATERIALS AND METHODS}

\section{Yoghurt processing}

Freeze dried direct vat set starter culture YF-L903 containing $9.37 \log$ CFU/g of Streptococcus thermophilus and $12.13 \log$ CFU/g Lactobacillus delbrueckii subsp. bulgaricus (Yo-Flex ${ }^{\circledR}, \quad \mathrm{Chr}$ Hansen, Valinhos, São Paulo, Brazil) were prepared according to BALTHAZAR et al. (2015). For each trial, a total of $12 \mathrm{~L}$ whole raw sheep (SM), cow (CM) and goat (GM) milks were obtained from farms located in Vassouras (Rio de Janeiro, Brazil), Miracema (Rio de Janeiro, Brazil) and São Gonçalo (Rio de Janeiro, Brazil), respectively, to produce $4 \mathrm{~L}$ of yoghurts from each species. The (SM), (CM) and (GM) were collected from animals' flock belonging to the breed Lacaune, Brazilian Girolando and Saanen, respectively. At pilot plant of Dairy Laboratory of Universidade Federal Fluminense, each type of milk was pasteurized at $85{ }^{\circ} \mathrm{C}$ for $30 \mathrm{~min}$ in a stainlesssteel double jacket container (GCA Corporation, Greensboro, North Carolina, United States) and cooled to $40{ }^{\circ} \mathrm{C}$. Aliquots from starter culture were inoculated at a concentration of $1 \%(\mathrm{v} / \mathrm{v})$ into whole pasteurized milk. After homogenization aliquots of milk $(200 \mathrm{~mL})$ from each species were transferred to flasks and fermented at $43{ }^{\circ} \mathrm{C}$ until the $\mathrm{pH}$ reached approximately 4.5 according to AOAC 981.12 for pH measurement of Acidified Foods (AOAC, 2012), followed by rapid cooling. Yoghurts from different species were stored during 28 days under refrigeration $\left(4{ }^{\circ} \mathrm{C}\right)$, and bacteriological, chemical, textural, and microstructural parameters were evaluated. When all the analysis were being evaluated, we certified that temperature was kept under $7{ }^{\circ} \mathrm{C}$ to avoid any detriment in the results. Two trials of yoghurt processing were performed for each species.

\section{Bacteriological analysis}

Streptococcus thermophilus count was performed utilizing M17 agar (Difco Company, Kansas, United States) and incubation at $37^{\circ} \mathrm{C}$ for $48 \mathrm{~h}$ under aerobic condition whereas, Lactobacillus delbrueckii ssp. bulgaricus was counted on MRS agar (Difco Company, Kansas, United States) at $37^{\circ} \mathrm{C}$ for $72 \mathrm{~h}$ under anaerobic condition utilizing anaerobic jar (Probac do Brasil, Rio de Janeiro, Brazil), both according to Codex Alimentarius standard for fermented milk in order to characterize the fermented product as yoghurt (Codex Alimentarius 2010). The bacteriological counts were analyzed in triplicate after yoghurt production on $1^{\text {st }}$ and $28^{\text {th }}$ days of storage $\left(4^{\circ} \mathrm{C}\right)$ for each trial. 


\section{Proximate composition}

Proximate composition was determined on the final product (day 1 of storage) in triplicate according to AOAC (2012) procedures for each trial. Yoghurt total solids content was determined by gravimetric method using a drying oven until constant weight (AOAC 925.23), protein content was estimated by the Kjeldahl technique (AOAC 991.22), lipid content was obtained by the Gerber method (AOAC 2000.18), and ash content was determined after incineration at $550{ }^{\circ} \mathrm{C}$ in muffle furnace (AOAC 945.46).

\section{Carbohydrates and organic acids}

Carbohydrates (lactose, galactose, and glucose) and organic acids (lactic, citric, and formic acids) were determined by high-performance liquid chromatography (HPLC). Extraction of these molecules was carried out as described by González de Llano et al. (1996) with slight modifications (COSTA et al., 2016b). Briefly, $5 \mathrm{~mL}$ of $\mathrm{H}_{2} \mathrm{SO}_{4}(45 \mathrm{mmol} / \mathrm{L})$ was added to $1 \mathrm{~g}$ of yoghurt samples and homogenized for $1 \mathrm{~min}$ in the vortex. Then, the solution was stirred for $1 \mathrm{~h}$ in a shaker table and centrifuged at 5,000 $\times g$ for $30 \mathrm{~min}$ at $4^{\circ} \mathrm{C}$. The decanted was collected and filtered through Whatman no.1 filter paper. Filtered samples were injected $(20 \mu \mathrm{L})$ in triplicate into HPLC system (Shimadzu ${ }^{\circledR}$ Kyoto, Japan) integrated with CBM-20A, connected to SPD-M20A diode array and refractive index RID-10A detectors. An Aminex HPX-87H column ( $300 \times 7.8 \mathrm{~mm})$ (Bio-Rad, Hercules, CA, USA), maintained at $60{ }^{\circ} \mathrm{C}$ by oven column, was used. Carbohydrates identification was performed by a refractive index detector, whereas organic acids with a diode array detector at $210 \mathrm{~nm}$. The chromatographic separation was achieved using $3 \mathrm{mM}$ sulfuric acid solution at the isocratic condition and a flow rate of $0.5 \mathrm{~mL} \cdot \mathrm{min}^{-1}$. Standard solutions of carbohydrates and organic acids (Sigma, St. Louis, MO) were utilized in order to plot external standard curves and carry out the quantitative analysis of the aforementioned molecules. All carbohydrates and organic acids were well separated in a 30-min total run time with good peak resolution, sharpness and symmetry. These analyses were evaluated in triplicate during the storage period $\left(4^{\circ} \mathrm{C}\right)$ on days $1,7,14,21$ and 28 for each trial.

\section{Analysis of $\mathrm{pH}$ and titratable acidity}

The $\mathrm{pH}$ values were measured according to NGUYEN et al. (2014a) with a digital pH meter (Digimed $^{\circledR}$ Model DM-32, São Paulo, Brazil). Yoghurts titratable acidity (TA) were determined by a volume of $0.5 \mathrm{~mL}$ of phenolphthalein $(5 \% \mathrm{w} / \mathrm{v})$, as an indicator added to $10 \mathrm{~g}$ of yoghurt following titration with $0.1 \mathrm{M}$ sodium hydroxide $(\mathrm{NaOH})$ solution to an end point of stable faint pink color for $1 \mathrm{~min}$; TA was expressed as lactic acid percentage (TAMJIDI et al., 2012). These analyses were performed in triplicate during fermentation and storage period $\left(4^{\circ} \mathrm{C}\right)$ on days $1,7,14,21$ and 28 for each trial.

\section{Firmness}

Firmness was determined at $5{ }^{\circ} \mathrm{C}$ by the Instrumental Texture Analyzer (TA-XT plus ${ }^{\circledR}$, Stable Micro System Ltd., Godalming, Waverley District, United Kingdom) equipped with a $5 \mathrm{~kg}$ load cell according to PASEEPHOL et al. (2008). Yoghurts were compressed with a $20 \mathrm{~mm}$ diameter cylindrical probe (36R) up to $10 \mathrm{~mm}$ depth at a constant speed $(1 \mathrm{~mm} / \mathrm{s})$. Gel firmness is characterized as maximum force $(\mathrm{N})$ on time force curve compression. This parameter was evaluated in triplicate for each trial on $1^{\text {st }}, 14^{\text {th }}$ and $28^{\text {th }}$ days of storage period.

\section{Apparent viscosity}

Apparent viscosity was evaluated at $5{ }^{\circ} \mathrm{C}$ utilizing a Rotational Viscometer Microprocessor (Q860M21, Quimis ${ }^{\circledR}$, Sao Paulo, SP, Brazil) with spindle number 4 . The spindle was rotated at 20 $\mathrm{rpm}$. Readings were recorded at the $30^{\text {th }}$ second of the measurement period and expressed as millipascal seconds (mPa.s), as described by BALTHAZAR et al. (2015). Apparent viscosity was performed in triplicate on $1^{\text {st }}, 14^{\text {th }}$ and $28^{\text {th }}$ days of the storage period for each trial.

\section{Water-holding capacity}

Water-holding capacity (WHC) was analyzed as described by REMEUF et al. (2003) with slight modifications. Yoghurt (Y) samples (20 g) were centrifuged (Hermle Z 360K, Wehingen, Germany) for $20 \mathrm{~min}$ at $4,500 \times g$ and $4{ }^{\circ} \mathrm{C}$. Expelled whey (EW) was removed and weighed. WHC was obtained in triplicate for each trial on $1^{\text {st }}, 14^{\text {th }}$ and $28^{\text {th }}$ days of the storage period. The WHC was calculated as: WHC $(\%)=100(\mathrm{Y}-\mathrm{WE}) / \mathrm{Y}$.

\section{Syneresis index}

Yoghurts syneresis index were performed according to DANNENBERG and KESSLER $\mathrm{H}$ (1988) with slight modifications and expressed as whey percentage weight separated from the gel. A yoghurt portion was removed with an ice cream scoop $(\mathrm{d}=45 \mathrm{~mm})$, in order to obtain approximately $29 \mathrm{~g}$ of hemispherical sample, and the flat side was 
placed onto a test sieve (mesh width $0.5 \mathrm{~mm}$ ). The whey volume $(\mathrm{mL})$ drained off was measured at $10{ }^{\circ} \mathrm{C}$ after $2 \mathrm{~h}$. Syneresis index was evaluated in triplicate for each trial on $1^{\text {st }}, 14^{\text {th }}$ and $28^{\text {th }}$ days of the storage period.

\section{Microstructural analysis}

Microstructural analysis was performed according to the method described by DOMAGAŁA et al. (2013) with slight modifications. Yoghurt samples microstructural characteristics were investigated using the scanning electron microscopy (SEM). Samples of $1 \mathrm{~cm}^{3}$ of each yoghurt were fixed overnight in $2.5 \%$ glutaraldehyde and $0.1 \mathrm{M}$ potassium cacodylate buffer at $4{ }^{\circ} \mathrm{C}$, rinsed (three times) with ultrafiltered water for $10 \mathrm{~min}$, post-fixed overnight in $2 \%$ osmium tetroxide. Further, the fixed and post-fixed yoghurt samples were dehydrated with ethanol solutions $(30 \%, 50 \%, 70 \%$ and $95 \%$ ) for $10 \mathrm{~min}$ each, and three times on $100 \%$ ethanol. An additional drying step using the critical point method with liquid carbon dioxide (Bal-Tec SCD 050, Balzers, Liechtenstein) was executed. Dry yoghurt samples were stuck on aluminum stubs with silver epoxy and gold-coated under vacuum using a sputter coater (Bal-Tec SCD 050, Balzers, Liechtenstein). Yoghurt microstructures were examined by SEM (Zeiss evo ma10, Oberkochen, Germany). Six fields were observed for each sample.

\section{Statistical analysis}

Analysis of variance (ANOVA) was used in order to assess the influence of species on yoghurt chemical and textural properties. Tukey's test was utilized to determine differences among means at 0.05 of significance level. Data were analyzed using XLSTAT version 2012.6.08 (Addinsoft, Paris, France).

\section{RESULTS AND DISCUSSION}

\section{Bacteriological analysis}

The bacteria count of yoghurts manufactured in the $1^{\text {st }}$ and $28^{\text {th }}$ day of the storage period utilizing milk from different species are presented in table 1. Bacteriological counts during storage period after fermentation characterized the fermented milk as yoghurt, according to Codex Alimentarius (2010), in which the minimum count required is $7.00 \mathrm{log} \mathrm{CFU} / \mathrm{g}$. The viability of great amount of lactic acid bacteria in yoghurts has been correlated with several benefits for consumer's health, such as high lactose tolerance, intestinal microflora benefic balance, antimicrobial activity
Table 1 - Bacteria count in the $1^{\text {th }}$ and $28^{\text {th }}$ day of storage period of yoghurts manufactured utilizing milk from different species

\begin{tabular}{lcccc}
\hline & \multicolumn{3}{c}{----------Bacteria count (log CFU/g)---------- } \\
\hline & \multicolumn{3}{c}{$\begin{array}{c}\text { Streptococcus } \\
\text { thermophilus }\end{array}$} & \multicolumn{2}{c}{$\begin{array}{c}\text { Lb. delbrueckii } \text { ssp. } \\
\text { bulgaricus }\end{array}$} \\
Treatments $^{*}$ & $1^{\text {th }}$ day & $28^{\text {th }}$ day & $1^{\text {th }}$ day & $28^{\text {th }}$ day \\
SY & 13.78 & 9.22 & 10.53 & 7.00 \\
CY & 13.83 & 10.02 & 12.22 & 8.15 \\
GY & 12.99 & 9.78 & 11.78 & 7.00 \\
\hline
\end{tabular}

*Treatments: sheep milk yoghurt (SY); cow milk yoghurt (CY); goat milk yoghurt (GY).

and immune system stimulation (BIROLLO et al., 2000). A decrease on bacterial counts was observed in the present study at the end of the storage period, by results reported by BEAL et al. (1999), BIROLLO et al. (2000), AKALIN et al. (2004).

\section{Proximate composition}

The proximate composition of the different raw milk species, as well as the breed of animals, substantially determines the final composition of the manufactured yogurts. Despite we have not detailed described different species raw milk composition in this research, the yogurt physical-chemical composition had already been determined and can be accessed in our research group previous publication (BALTHAZAR et al., 2015, VIANNA et al., 2017). In the present study, SY demonstrated greater $(P<0.05)$ total solids, protein, and lipid contents than $\mathrm{CY}$ and $\mathrm{GY}$, whereas these differences were not detected $(P>0.05)$ between CY and GY (Table 2). Moreover, the three types of yoghurt exhibited similar $(P>0.05)$ ash content. In general, sheep milk contains greater total solids, protein and lipid content than goat and cow milk (PARK, 2007), which potentially reflected on the differences above.

In accordance with the present research results, (ERKAYA \& ŞENGÜL, 2012) studied yoghurts produced utilizing milk from different species and observed greater total solids, protein and lipid content in sheep milk yoghurt when compared to cow and goat milk yoghurts. GÜLER \& SANAL (2009) also documented greater protein and lipid content in sheep milk yoghurt than cow and goat milk yoghurts; moreover, chemical composition of yoghurt produced with cow milk was similar to goat counterpart. In addition, GÜLER \& GÜRSOY-BALCI 
Table 2 - Proximate composition of yoghurts manufactured utilizing milk from different species.

\begin{tabular}{|c|c|c|c|c|}
\hline \multirow[t]{2}{*}{ Treatments ${ }^{*}$} & - & Proximate con & 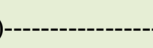 & 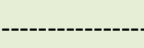 \\
\hline & Total solids & Protein & Lipid & Ash \\
\hline SY & $19.48 \pm 0.00^{\mathrm{a}}$ & $5.32 \pm 0.00^{\mathrm{a}}$ & $6.08 \pm 0.00^{\mathrm{a}}$ & $1.03 \pm 0.00^{\mathrm{a}}$ \\
\hline $\mathrm{CY}$ & $14.49 \pm 0.04^{\mathrm{b}}$ & $3.89 \pm 0.01^{\mathrm{b}}$ & $4.39 \pm 0.01^{b}$ & $0.78 \pm 0.00^{\mathrm{a}}$ \\
\hline GY & $12.51 \pm 0.00^{b}$ & $3.16 \pm 0.00^{b}$ & $3.44 \pm 0.00^{\mathrm{b}}$ & $0.77 \pm 0.00^{\mathrm{a}}$ \\
\hline
\end{tabular}

*Treatments: sheep milk yoghurt (SY); cow milk yoghurt (CY); goat milk yoghurt (GY).

Results $(n=6)$ are expressed as the mean \pm standard deviation.

Means without common superscripts $(\mathrm{a}-\mathrm{b})$ in a column are different $(P<0.05)$.

(2011) produced yoghurts using sheep and goat milk and their mixture. These authors also observed that sheep milk yoghurt obtained greater values of total solids, protein and lipid than goat milk yoghurt.

\section{Carbohydrates profile}

Carbohydrates contents values from SY, $\mathrm{CY}$ and GY are presented in table 3. On the first day (day 1) of storage while CY and GY demonstrated greater $(P<0.05)$ lactose content than SY whereas, SY exhibited the greatest $(P<0.05)$ galactose content; after day 7 of storage, no difference $(P>0.05)$ on the aforementioned molecule's contents was observed among all yoghurts. Furthermore, during the storage period, the lactose and galactose content values in SY remained similar $(P>0.05)$ whereas, on $\mathrm{CY}$ and GY the lactose content decreased $(P<0.05)$, and the galactose values increased $(P<0.05)$. In contrast, the SY and CY glucose content were detected just at the beginning of storage, while GY demonstrated fluctuations $(P<0.05)$ during the yoghurt storage period.

Lactose is the major carbohydrate in goat, sheep and cow milk and is composed by glucose and galactose monomers (PEREIRA DA COSTA \& CONTE-JUNIOR, 2015). In general, sheep and cow milk types contain similar lactose levels (Park et al. 2007), which are greater than goat milk (MAYER \& FIECHTER, 2012). Greater lactose content in milk can positively influence the yoghurt texture as due to the ability of the starter microorganisms to produce an exopolysaccharide (EPS) from this carbohydrate (TAMIME \& ROBINSON, 2007). In this context, the lower values of lactose with greater content of galactose on SY than on CY and GY, at the beginning of storage, is potentially due to the hydrolysis of lactose into galactose by starter microorganisms during the fermentation period. Conversely, CY and GY demonstrated a slight decrease, which can be explained by this molecule consumption during storage with the release of galactose from lactose hydrolysis (FARNWORTH, 2008). The GY glucose content fluctuations during storage period can be attributed to glucose consumption (KAMINARIDES et al., 2007) and through lactose conversion by yoghurt microorganisms (VÉNICA et al., 2014). Similar to our results, (DOMAGAŁA, 2009) documented that lactose content values in cow and goat milk yoghurts were similar. Moreover, in partial agreement with the present research, (VÉNICA et al., 2014) reported an increase in galactose and lactic acid content, with a simultaneous decline in lactose content in fermented products manufactured with sheep and cow milk.

\section{Organic acids profile}

Organic acids values from yoghurts manufactured utilizing SM, CM and GM are exhibited in table 3. CY exhibited the lowest $(P<0.05)$ lactic acid content, and GY the greatest $(P<0.05)$ values from day 21 of storage. In addition, all yoghurt treatments demonstrated a lactic acid content increase $(P<0.05)$ during the yoghurt storage period. In general, SY exhibited greater $(P<0.05)$ citric and formic acid contents than CY and GY. Moreover; although, SY and $\mathrm{CY}$ citric acid content values exhibited an increase $(P<0.05)$, GY did not exhibit $(P>0.05)$ difference during the storage period. Furthermore, formic acid content generally remained similar $(P>0.05)$ in all yoghurt treatments during the storage period.

Lactic acid is the major final product of lactic acid bacteria fermentative energy metabolism and its increase in yoghurts is common after refrigerated storage (DE ANCOS et al., 2000) due to the lactose utilization by starter cultures (TAMIME \& ROBINSON, 2007), which explains the slight lactose decrease and lactic acid increase observed in the present research. According to (GRANATA \& MORR, 1996), the adequate lactic acid amount can positively contribute with yoghurt texture leading to a minimum 
Table 3 - Carbohydrates and organic acids content values of yoghurts manufactured utilizing milk from different species.

\begin{tabular}{|c|c|c|c|c|c|c|}
\hline \multicolumn{2}{|c|}{ Molecules (mg/mL) } & \multicolumn{5}{|c|}{ 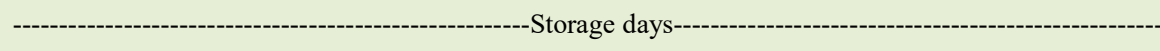 } \\
\hline & ${ }^{*}(\mathrm{~T})$ & 1 & 7 & 14 & 21 & 28 \\
\hline \multirow[t]{3}{*}{ Lactose } & SY & $48.66 \pm 0.78^{\mathrm{bA}}$ & $46.90 \pm 0.55^{\mathrm{aA}}$ & $45.39 \pm 0.87^{\mathrm{aA}}$ & $44.84 \pm 0.93^{\mathrm{aA}}$ & $44.16 \pm 1.85^{\mathrm{aA}}$ \\
\hline & $\mathrm{CY}$ & $54.20 \pm 0.79^{\mathrm{aA}}$ & $48.50 \pm 0.37^{\mathrm{aAB}}$ & $44.34 \pm 1.82^{\mathrm{aB}}$ & $43.12 \pm 3.02^{\mathrm{aB}}$ & $43.08 \pm 0.14^{\mathrm{aB}}$ \\
\hline & GY & $52.73 \pm 0.49^{\mathrm{aA}}$ & $50.62 \pm 0.46^{\mathrm{aA}}$ & $42.84 \pm 0.20^{\mathrm{aB}}$ & $42.88 \pm 2.46^{\mathrm{aB}}$ & $43.10 \pm 0.41^{\mathrm{aB}}$ \\
\hline \multirow[t]{3}{*}{ Galactose } & SY & $6.17 \pm 0.15^{\mathrm{aA}}$ & $6.40 \pm 0.69^{\mathrm{aA}}$ & $6.72 \pm 1.16^{\mathrm{aA}}$ & $6.45 \pm 0.08^{\mathrm{aA}}$ & $6.66 \pm 0.43^{\mathrm{aA}}$ \\
\hline & $\mathrm{CY}$ & $5.05 \pm 0.59^{\mathrm{bB}}$ & $5.79 \pm 0.17^{\mathrm{aAB}}$ & $5.81 \pm 0.14^{\mathrm{aAB}}$ & $5.70 \pm 0.38^{\mathrm{aAB}}$ & $5.87 \pm 0.09^{\mathrm{aA}}$ \\
\hline & GY & $4.82 \pm 0.20^{\mathrm{bB}}$ & $5.27 \pm 0.46^{\mathrm{aAB}}$ & $5.67 \pm 0.08^{\mathrm{aAB}}$ & $5.81 \pm 0.81^{\mathrm{aAB}}$ & $6.69 \pm 0.43^{\mathrm{aA}}$ \\
\hline \multirow[t]{3}{*}{ Glucose } & SY & $0.23 \pm 0.00^{\mathrm{bA}}$ & $0.13 \pm 0.03^{\mathrm{aA}}$ & ND & ND & ND \\
\hline & $\mathrm{CY}$ & $0.54 \pm 0.00^{\mathrm{a}}$ & ND & ND & ND & ND \\
\hline & GY & $0.09 \pm 0.00^{\mathrm{cAB}}$ & $0.20 \pm 0.03^{\mathrm{aA}}$ & ND & $0.05 \pm 0.02^{\mathrm{B}}$ & ND \\
\hline \multirow[t]{3}{*}{ Lactic acid } & SY & $17.00 \pm 0.16^{\mathrm{aC}}$ & $17.41 \pm 0.01^{\mathrm{abC}}$ & $18.20 \pm 0.13^{\mathrm{aB}}$ & $20.50 \pm 0.00^{\mathrm{bA}}$ & $20.54 \pm 0.04^{\mathrm{bA}}$ \\
\hline & $\mathrm{CY}$ & $14.85 \pm 0.23^{\mathrm{bC}}$ & $16.21 \pm 0.97^{\mathrm{bBC}}$ & $16.25 \pm 0.03^{\mathrm{bBC}}$ & $16.86 \pm 0.02^{\mathrm{cAB}}$ & $18.38 \pm 0.18^{\mathrm{cA}}$ \\
\hline & GY & $17.26 \pm 0.06^{\mathrm{aD}}$ & $18.74 \pm 1.84^{\mathrm{aC}}$ & $18.83 \pm 0.23^{\mathrm{aC}}$ & $21.45 \pm 0.13^{\mathrm{aB}}$ & $22.95 \pm 0.04^{\mathrm{aA}}$ \\
\hline \multirow[t]{3}{*}{ Citric acid } & SY & $7.02 \pm 0.06^{\mathrm{aC}}$ & $8.10 \pm 0.25^{\mathrm{aAB}}$ & $7.78 \pm 0.17^{\mathrm{aB}}$ & $8.15 \pm 0.03^{\mathrm{aAB}}$ & $8.42 \pm 0.04^{\mathrm{aA}}$ \\
\hline & $\mathrm{CY}$ & $5.57 \pm 0.06^{\mathrm{bB}}$ & $6.63 \pm 0.08^{\mathrm{bAB}}$ & $7.14 \pm 0.42^{\mathrm{aA}}$ & $6.89 \pm 0.58^{\mathrm{abA}}$ & $7.10 \pm 0.01^{\mathrm{bA}}$ \\
\hline & GY & $5.16 \pm 0.00^{\mathrm{cA}}$ & $5.55 \pm 0.10^{\mathrm{cA}}$ & $6.05 \pm 0.86^{\mathrm{aA}}$ & $6.51 \pm 0.33^{\mathrm{bA}}$ & $6.66 \pm 0.07^{\mathrm{cA}}$ \\
\hline \multirow[t]{3}{*}{ Formic acid } & SY & $5.75 \pm 0.08^{\mathrm{aA}}$ & $7.09 \pm 0.00^{\mathrm{aA}}$ & $6.58 \pm 0.27^{\mathrm{aA}}$ & $6.77 \pm 0.73^{\mathrm{aA}}$ & $6.93 \pm 0.00^{\mathrm{aA}}$ \\
\hline & $\mathrm{CY}$ & $5.19 \pm 0.08^{\mathrm{bB}}$ & $6.05 \pm 0.09^{\mathrm{bA}}$ & $6.05 \pm 0.01^{\mathrm{aA}}$ & $5.81 \pm 0.19^{\mathrm{aA}}$ & $6.04 \pm 0.18^{\mathrm{bA}}$ \\
\hline & GY & $3.53 \pm 0.02^{\mathrm{cA}}$ & $3.58 \pm 0.17^{\mathrm{cA}}$ & $3.54 \pm 0.05^{\mathrm{bA}}$ & $3.88 \pm 0.18^{\mathrm{bA}}$ & $3.89 \pm 0.15^{\mathrm{cA}}$ \\
\hline
\end{tabular}

${ }^{*}(\mathrm{~T})=$ Treatments: sheep milk yoghurt (SY); cow milk yoghurt (CY); goat milk yoghurt (GY).

\#ND = not detected.

Results $(n=6)$ are expressed as the mean \pm standard deviation.

Means without common superscripts $(\mathrm{A}-\mathrm{D})$ in a row are different $(P<0.05)$.

Means without common superscripts $(\mathrm{a}-\mathrm{c})$ in a column within a molecule are different $(P<0.05)$.

syneresis index during the storage period. In the present research, GY obtained the greatest acid lactic content at the end of yoghurt storage $\left(21^{\text {th }}\right.$ and $28^{\text {th }}$ storage days) (Table 3), which potentially lead to an effect on the aforementioned yoghurt texture. Although, SY lactic acid content was similar to GY between the $1^{\text {st }}$ and $14^{\text {th }}$ storage day, SY obtained the greatest total solids and protein content (Table 2). Therefore the lactic acid content alone may not affect SY textural properties. Citric acid is the most abundant organic acid present in raw milk (TORMO \& IZCO, 2004) thus, the observed citric acid content values increase indicates negligible citric acid utilization by starter cultures during storage (ADHIKARI et al., 2002).

In agreement with results reported in the present study, KAMINARIDES et al. (2007) concluded that sheep milk yoghurt with elevated fat content obtained greater texture scores such as firmness and lower syneresis index than other low- regularfat treatments. The concentration of lactic acid in the aforementioned yoghurt was lower than those produced with different fat content. Thus the absence of textural defects in that study can be due to the sheep milk high total solids and low lactic acid content. In agreement with the present research, HERRERO \& REQUENA (2006) evaluated the effect of supplementing goat milk with whey protein concentrate (WPC) on set-type yoghurt textural properties and reported that WPC increases the lactic acid content.

\section{Analysis of $\mathrm{pH}$ and titratable acidity}

Yoghurt $\mathrm{pH}$ and TA values from different species during storage period are exhibited in table 4. The SY, CY, and GY did not demonstrate $(P>0.05)$ difference among $\mathrm{pH}$ values. When compared day 1 and 28 of the storage period $\mathrm{CY}$ exhibited a decrease $(P<0.05)$ on the $\mathrm{pH}$ values. In addition, milk from different species affected $(P<0.05)$ yoghurt TA; SY values were greater $(P<0.05)$ than CY and GY. Also, during the storage period while the TA values of SY increased $(P<0.05) \mathrm{CY}$ and GY were not affected $(P>0.05)$.

The observed $\mathrm{pH}$ results were expected based on the usual yoghurt $\mathrm{pH}$ decrease during storage period (LUCEY, 2004). The slight TA increase and $\mathrm{pH}$ decrease observed during storage period could 
Table 4 - Values of $\mathrm{pH}$ and titratable acidity of yoghurts manufactured utilizing milk from different species.

\begin{tabular}{|c|c|c|c|c|c|c|}
\hline Parameters & ${ }^{*}(\mathrm{~T})$ & 1 & 7 & 14 & 21 & 28 \\
\hline \multicolumn{7}{|c|}{ 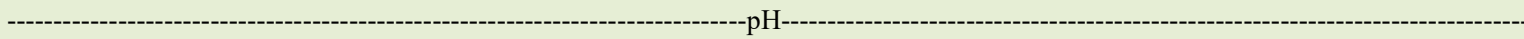 } \\
\hline & SY & $4.66 \pm 0.03^{\mathrm{aA}}$ & $4.59 \pm 0.08^{\mathrm{aA}}$ & $4.54 \pm 0.08^{\mathrm{aA}}$ & $4.51 \pm 0.07^{\mathrm{aA}}$ & $4.50 \pm 0.06^{\mathrm{aA}}$ \\
\hline & CY & $4.56 \pm 0.09^{\mathrm{aA}}$ & $4.49 \pm 0.09^{\mathrm{aAB}}$ & $4.46 \pm 0.08^{\mathrm{aAB}}$ & $4.45 \pm 0.07^{\mathrm{aAB}}$ & $4.42 \pm 0.07^{\mathrm{aB}}$ \\
\hline & GY & $4.62 \pm 0.08^{\mathrm{aA}}$ & $4.59 \pm 0.09^{\mathrm{aA}}$ & $4.54 \pm 0.06^{\mathrm{aA}}$ & $4.51 \pm 0.06^{\mathrm{aA}}$ & $4.48 \pm 0.08^{\mathrm{aA}}$ \\
\hline \multicolumn{7}{|c|}{ 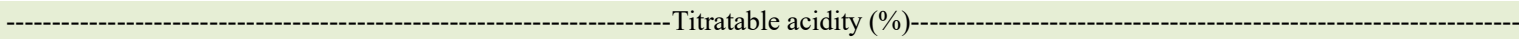 } \\
\hline & SY & $0.92 \pm 0.00^{\mathrm{aC}}$ & $0.96 \pm 0.00^{\mathrm{aBC}}$ & $0.99 \pm 0.00^{\mathrm{aB}}$ & $1.01 \pm 0.00^{\mathrm{aAB}}$ & $1.05 \pm 0.00^{\mathrm{aA}}$ \\
\hline & $\mathrm{CY}$ & $0.70 \pm 0.00^{\mathrm{bA}}$ & $0.73 \pm 0.00^{\mathrm{bA}}$ & $0.74 \pm 0.00^{\mathrm{bA}}$ & $0.76 \pm 0.00^{\mathrm{bA}}$ & $0.78 \pm 0.00^{\mathrm{bA}}$ \\
\hline & GY & $0.72 \pm 0.00^{\mathrm{bA}}$ & $0.74 \pm 0.00^{\mathrm{bA}}$ & $0.76 \pm 0.00^{\mathrm{bA}}$ & $0.77 \pm 0.00^{\mathrm{bA}}$ & $0.80 \pm 0.00^{\mathrm{bA}}$ \\
\hline
\end{tabular}

${ }^{*}(\mathrm{~T})=$ Treatments: sheep milk yoghurt (SY); cow milk yoghurt (CY); goat milk yoghurt (GY).

Results $(n=6)$ are expressed as the mean \pm standard deviation.

Means without common superscripts $(\mathrm{A}-\mathrm{C})$ in a row are different $(P<0.05)$.

Means without common superscripts $(\mathrm{a}-\mathrm{b})$ in a column within a parameter are different $(P<0.05)$.

be due to lactic acid production through lactose hydrolysis promoted by starter culture and lactic acid bacteria (LOURENS-HATTINGH \& VILJOEN, 2001; KAILASAPATHY, 2006). Nevertheless, the observed $\mathrm{pH}$ decreases on $\mathrm{CY}$ samples at the $28^{\text {th }}$ day of storage is potentially due to the lower buffering capacity of cow milk than goat (PARK et al., 2007) and sheep counterparts. Moreover, the observed increase of TA on SY can be due to greater buffering capacity associated with greater mineral, protein and dissolved $\mathrm{CO}_{2}$ content than cow and goat milks (SALAÜN et al., 2005). Consequently, it leads to a greater alkali solution volume during titration step.

In agreement with the present research, DOMAGAŁA (2009), ERKAYA \& ŞENGÜL (2012) reported that sheep dairy product (milk and yoghurt, respectively) exhibited greater TA values than goat and cow counterparts, demonstrating that the effect on this parameter is specie-specific. Furthermore, ERKAYA \& ŞENGÜL (2012) documented similar $\mathrm{pH}$ values for goat and sheep milk yoghurts, and the $\mathrm{pH}$ decrease associated with an increase on TA values on yoghurt from different species during storage is in accordance with other studies using cow (MATARAGAS et al., 2011), buffalo (ERKAYA \& ŞENGÜL, 2012), sheep and goat (GÜLER \& GÜRSOY-BALCI, 2011; ERKAYA \& ŞENGÜL, 2012) milk.

\section{Firmness}

Firmness, apparent viscosity, WHC, and syneresis from yoghurts produced utilizing milk from three different species (sheep, cow, and goat) are presented in table 5. The SY were firmer $(P<0.05)$ than $\mathrm{CY}$ and GY during all storage period. Moreover, on day 14 and 28 of the storage period, CY firmness was greater $(P<0.05)$ than GY. In addition, the storage period only affected $(P<0.05) \mathrm{GY}$, demonstrating a decrease in textural quality in this type of yoghurt.

Firmness is considered one of the main textural parameters for yoghurt acceptability (HARTE et al., 2007). During coagulation step on yoghurt manufacturing, destabilized casein micelles and calcium-phosphate bonds form a network, which in turn entraps fat and other solids (COSTA et al., 2015b). The speed of casein network formation is directly influenced by protein amount, mainly casein content, resulting in greater aggregation rate with firmer curd development (DIMASSI et al., 2005). Differences on total solids content among milk from different species affect yoghurt curd firmness (PARK et al., 2007), which can be evidenced in SY firmness (Table 5) with greater $(P<0.05)$ total solids and protein content (Table 2) when compared with the other two yoghurt types studied.

Furthermore, MARTÍN-DIANA et al. (2003) demonstrated that firmness can also be influenced by milk casein content and micelle structure from each species. According to these authors; although, total solids content for cow and goat milk were similar, yoghurts produced with goat milk tends to be less firm than cow milk yoghurt; in the present study; although, GY and $\mathrm{CY}$ demonstrated similar $(P>0.05)$ proximate composition values (Table 2), the first one was firmer $(P<0.05)$ than the latter (Table 5). In addition, AND $\&$ GUO (2006) reported that goat milk exhibits less 
Table 5 - Textural properties of yoghurts manufactured utilizing milk from different species.

\begin{tabular}{|c|c|c|c|c|}
\hline Parameters & ${ }^{*}(\mathrm{~T})$ & 1 & 14 & 28 \\
\hline \multicolumn{5}{|c|}{ 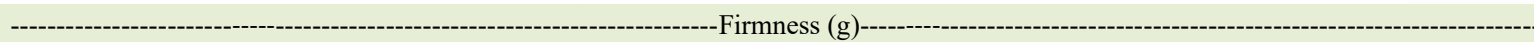 } \\
\hline & SY & $7.66 \pm 0.80^{\mathrm{aA}}$ & $7.70 \pm 0.27^{\mathrm{aA}}$ & $8.02 \pm 0.46^{\mathrm{aA}}$ \\
\hline & $\mathrm{CY}$ & $2.18 \pm 0.23^{\mathrm{bA}}$ & $2.12 \pm 0.00^{\mathrm{bA}}$ & $1.97 \pm 0.22^{\mathrm{bA}}$ \\
\hline & GY & $0.70 \pm 0.03^{\mathrm{bA}}$ & $0.44 \pm 0.00^{\mathrm{cB}}$ & $0.43 \pm 0.03^{\mathrm{cB}}$ \\
\hline \multicolumn{5}{|c|}{--1--1 } \\
\hline & SY & $785.52 \pm 3.46^{\mathrm{aA}}$ & $779.85 \pm 1.63^{\mathrm{aA}}$ & $777.47 \pm 2.58^{\mathrm{aA}}$ \\
\hline & $\mathrm{CY}$ & $721.45 \pm 23.36^{\mathrm{aA}}$ & $675.43 \pm 13.97^{\mathrm{bA}}$ & $650.65 \pm 45.00^{\mathrm{bA}}$ \\
\hline & GY & $223.60 \pm 15.70^{\mathrm{bA}}$ & $214.45 \pm 17.18^{\mathrm{cA}}$ & $199.03 \pm 10.15^{\mathrm{cA}}$ \\
\hline \multicolumn{5}{|c|}{ - } \\
\hline & SY & $94.51 \pm 0.02^{\mathrm{aA}}$ & $94.56 \pm 0.01^{\mathrm{aA}}$ & $93.66 \pm 0.00^{\mathrm{aA}}$ \\
\hline & CY & $69.82 \pm 0.02^{\mathrm{bA}}$ & $68.99 \pm 0.04^{\mathrm{bA}}$ & $66.98 \pm 0.02^{\mathrm{bA}}$ \\
\hline & GY & $56.71 \pm 0.03^{\mathrm{cA}}$ & $54.03 \pm 0.05^{\mathrm{cA}}$ & $53.45 \pm 0.01^{\mathrm{cA}}$ \\
\hline \multicolumn{5}{|c|}{ 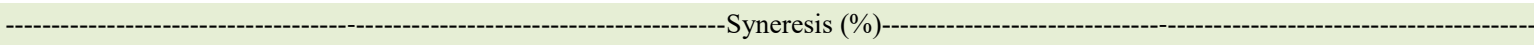 } \\
\hline & SY & $11.21 \pm 0.00^{\mathrm{cA}}$ & $11.25 \pm 0.00^{\mathrm{cA}}$ & $11.26 \pm 0.00^{\mathrm{cA}}$ \\
\hline & $\mathrm{CY}$ & $35.57 \pm 0.02^{\mathrm{bA}}$ & $38.26 \pm 0.01^{\mathrm{bA}}$ & $39.10 \pm 0.00^{\mathrm{bA}}$ \\
\hline & GY & $44.35 \pm 0.01^{\mathrm{aA}}$ & $50.14 \pm 0.03^{\mathrm{aA}}$ & $51.18 \pm 0.02^{\mathrm{aA}}$ \\
\hline
\end{tabular}

${ }^{*}(\mathrm{~T})=$ Treatments: sheep milk yoghurt (SY); cow milk yoghurt (CY); goat milk yoghurt (GY).

\# Water-Holding Capacity.

Results $(n=6)$ are expressed as the mean \pm standard deviation.

Means without common superscripts $(\mathrm{A}-\mathrm{B})$ in a row are different $(P<0.05)$.

Means without common superscripts $(\mathrm{a}-\mathrm{c})$ in a column within a parameter are different $(P<0.05)$.

as1-casein content than cow milk which potentially explains the less consistency on GY.

In agreement with observed firmness results, DOMAGAŁA (2008), ZUBEIR et al. (2012) demonstrated that sheep milk yoghurt was firmer than goat milk yoghurt. Moreover, DOMAGAŁA (2009) evaluated different textural parameters, such as hardness, adhesiveness and extrusion force among sheep, cow and goat milk yoghurts and demonstrated that yoghurts produced from goat milk exhibited the lowest values of textural parameters whereas, sheep milk yoghurts, the greatest ones; indicating that total solids and protein content can be considered important parameters to determine final product textural characteristics. In partial agreement with the present study, AMATAYAKUL et al. (2006) investigated firmness of set-yoghurts produced with different casein to whey ratios, as well as total solids content, and observed that the firmness did not change during storage. Additionally, KATSIARI et al. (2002) evaluated the effects of long-term deep-frozen storage on yoghurt characteristics and demonstrated that during cold storage, sheep milk yoghurt firmness slightly increased.

\section{Apparent viscosity}

This research demonstrated that apparent viscosity parameter was affected $(P<0.05)$ by type of milk (different species) used to produce yoghurts. During all the storage period analyzed, GY obtained the lowest $(P<0.05)$ apparent viscosity, whereas SY exhibited the greatest $(P<0.05)$ values at days 14 and 28 of storage. In addition, the storage period did not affect $(P>0.05)$ this parameter's values during storage period for all yoghurt types.

Variations on apparent viscosity results observed in the present study can be attributed to differences in total solids and protein content among milk types (JUMAH et al., 2001; MARTÍNDIANA et al., 2003). Usually, yoghurt produced with cow and goat milk require fortification in order to improve total solids content and consequently yoghurt viscosity (REMEUF et al., 2003; HERRERO \& REQUENA, 2006) as sheep milk yoghurt already contains high total solids content, the fortification step is not required (BOYAZOGLU \& MORAND-FEHR, 2001). In accordance with aforementioned results, (KÜÇÜKÇETIN et al., 2011; ERKAYA \& ŞENGÜL, 2012; WANG et al., 2012) evaluated apparent viscosity 
among yoghurt samples produced from different types of milk (goat, cow, and their mixture), and observed that yoghurt viscosity obtained from goat milk was lower than cow milk yoghurt and their mixtures.

\section{Water-holding capacity}

During all storage period analyzed, SY exhibited the greatest $(P<0.05)$ WHC values, whereas GY the lowest $(P<0.05)$ ones. Furthermore, storage period did not influence $(P>0.05)$ this parameter. Total solids and protein content directly affected WHC, potentially due to greater milk proteins content which increases yoghurt gel network density, and consequently the WHC (KRASAEKOOPT et al., 2004). SODINI et al. (2004) reported that an increase in casein concentration can favor its micelles interaction as well as, leading to decrease of matrix pore dimensions and an increase of its density. In addition; although, GY and CY demonstrated similar total solids and protein contents (Table 2), GY exhibited lower $(P<0.05)$ WHC values, which can be explained by differences on micelle hydration between these aforementioned types of milk (goat milk is less hydrated than cow milk) (PARK et al., 2007).

LE et al. (2011) compared yoghurts with a similar amount of dry solids content containing an increased milk fat globule membrane material concentration and observed a WHC improvement due to an increase in total solids content. Moreover, KÜÇÜKÇETIN et al. (2011) observed that yoghurt produced with goat milk obtained lower WHC than yoghurts manufactured utilizing cow milk. In addition, MALEK et al. (2001) reported that; although, yoghurts produced with cow and goat milk demonstrated similar total solids content, the former one released less water than those obtained from goat milk.

\section{Syneresis index}

The yoghurt syneresis index was $(P<0.05)$ affected by milk type but not by storage period $(P>0.05)$. In contrast with WHC, the lowest $(P<0.05)$ syneresis index value was observed in SY whereas, the greatest $(P<0.05)$ one in GY during all the storage period analyzed. Syneresis represents an important concern in yoghurt commercial manufacturing, which can lead to accumulation of whey (serum) on yoghurt gel surface, decreasing the consumer acceptance (GHASEMPOUR et al., 2012). According to AMATAYAKUL et al. (2006), an increase in total solids content favors syneresis decrease potentially clarifying why yoghurt samples that demonstrated the greatest total solids content, obtained the lowest syneresis index. Casein and colloidal calcium content also affect syneresis index. Thus, the greater sheep milk micelles mineralization levels than cow and goat milk (PARK et al., 2007), may explain the SY lowest syneresis index. Furthermore, in agreement with this study, DOMAGAŁA (2009), ERKAYA \& ŞENGÜL, (2012) demonstrated that yoghurts from goat milk exhibited greater syneresis index than yoghurts produced with sheep milk.

\section{Microstructural analysis}

The scanning electron micrographs obtained from yoghurts elaborated with sheep, cow and goat milk are depicted in figure 1 and 2 . The figures illustrate the yoghurt protein network microstructure entrapping fat globules and void
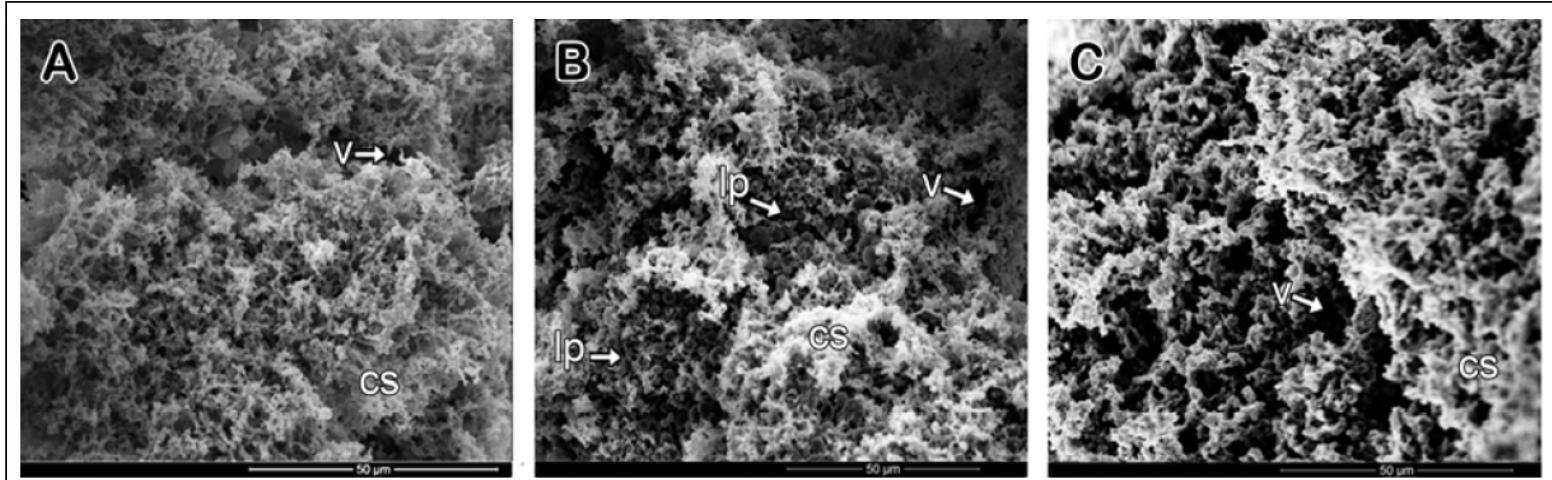

Figure 1 - Scanning electron microscopy (SEM) micrographs of yoghurts manufactured with sheep milk (A), cow milk (B) and goat milk (C). Bar $=50 \mu \mathrm{m}$. v, void space; cs, casein, lp, lipid. 
spaces (Figure 1,2) filled with bacterial cells (Figure 2). Yoghurt consists of a network composed by clusters or chains of casein particles forming a three-dimensional matrix (PENNA et al., 2007). Microstructural differences among the three yoghurt types were visualized. As depicted in figure 1, SY (Figure 1A) was characterized by a denser structure exhibiting fewer pores structure than $\mathrm{CY}$ (Figure 1B) and GY (Figure 1C), which in turn exhibited a more open structure. In addition, SY (Figure 2a) exhibited a more branched-structured gel and more interconnected clusters, demonstrating a very fine network composed by small and homogeneous void spaces, embedded with fat globules and bacterial cells. These observations support the strong link between yoghurt gel microstructure and textural properties. SY exhibited greater firmness, apparent viscosity and, water-holding capacity, and lower syneresis index values than CY and GY (Table 5); finer protein chains, smaller casein particles and pore sizes improves water immobilization (KRZEMINSKI et al., 2011). The GY (Figure 2c) exhibited plenty of void spaces with heterogeneous size and irregular microstructure, as well as CY; however, GY presented a coarser gel structure and large clusters, suggesting differences on micelle characteristics among the three studied yoghurt types. These GY microstructural differences can be explained due to differences in casein fraction relative proportions in goat milk when compared with cow and sheep milk.

TAMIME and ROBINSON (2007) also reported that the porosity of yoghurt gel was more compact or denser in sheep milk yoghurt than cow counterpart. As described by PARK et al. (2007), the casein micelle structure of cow milk differs from sheep milk in diameter, hydration and mineralization in addition to the smaller fat globule size on sheep milk than in cow counterpart potentially explain the CY weaker gel structure in comparison with SY. Furthermore, NGUYEN et al. (2014a) reported that other parameters in addition to total solids content, such as concentration of lactose, calcium, and fat globules as well as, fat globules surface area also influence yoghurt structure and textural properties. Thus, the observed differences among CY, SY and GY are potentially attributed to differences in milk physicochemical characteristics. Moreover, caprine casein micelles contain more calcium and inorganic phosphorus, and are less solvated, less heat stable, and release $\beta$-casein more rapidly than bovine casein micelles (PARK et al., 2007). During fermentation, the decrease in $\mathrm{pH}$ values closer to the casein micelles isoelectric point ( $\mathrm{pH} 4.6$ ) favors the colloidal calcium phosphate solubilization, increasing hydrophobic interaction. Ultimately, causing casein micelles aggregation into a three-dimensional chain network, LUCEY (2004) \& (PHADUNGATH, (2005) demonstrated that casein micelles play an important role in milk acid coagulation. In agreement with this research, DOMAGAŁA (2009) reported that goat milk yoghurt microstructure was more delicate, less resistant to deformation and more susceptible to syneresis than cow and sheep counterparts; sheep milk yoghurt exhibited the strongest gel matrix. Additionally, VARGAS et al. (2008) demonstrated that yoghurt formulations with $100 \%$ of goat milk were characterized by a smaller number of junction points, which led to a more open structure with larger pores and a greater number of smaller fat globules than formulations with $100 \%$ cow milk.
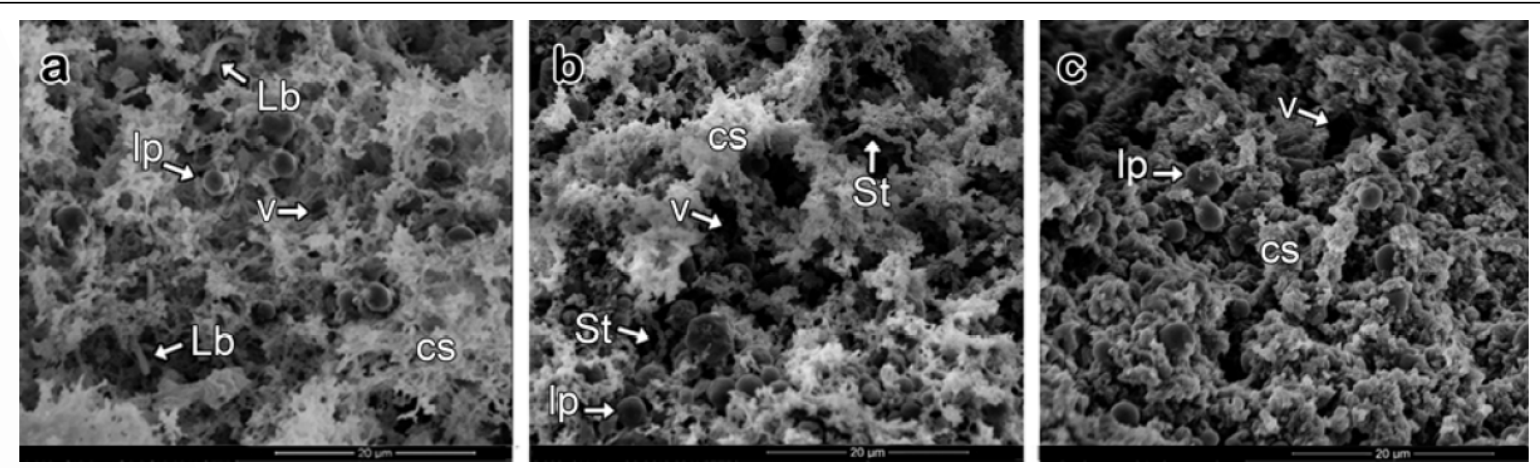

Figure 2 - Scanning electron microscopy (SEM) micrographs of yoghurts produced with sheep milk (a), cow milk (b) and goat milk (c). Bar $=20 \mu \mathrm{m}$. St, Streptococcus thermophilus; Lb, Lactobacillus delbrueckii ssp. bulgaricus; v, void space; cs, casein, lp, lipid 


\section{CONCLUSION}

The chemical parameters of yoghurts, mainly total solids, protein, lipid and lactic acid content are specie-specific. These differences potentially affected textural and microstructural yoghurt properties. The present study demonstrated a clear correlation among chemical, textural, and microstructural yoghurt parameters. Sheep milk produced yoghurt with the most desirable textural characteristics for consumer market while goat milk yoghurt exhibited the lowest attractive textural properties. In Brazil, the extensive livestock area, the large cattle farming and the popular culture of the cow milk consume are reasons why sheep's milk yogurt is not produced on a commercial scale yet. Nevertheless, sheep milk yoghurt can be considered a suitable alternative to cow milk yoghurt, especially in states with a low level of cattle production like Rio de Janeiro.

\section{ACKNOWLEDGEMENTS}

"This study was financed in part by the Coordenação de Aperfeiçoamento de Pessoal de Nível Superior (CAPES), Brasil - Finance code 001".

\section{DECLARATION OF CONFLICT OF INTERESTS}

The authors declare no conflict of interest. The founding sponsors had no role in the design of the study; in the collection, analyses, or interpretation of data; in the writing of the manuscript, and in the decision to publish the results.

\section{AUTHORS' CONTRIBUTIONS}

All authors contributed equally for the conception and writing of the manuscript. All authors critically revised the manuscript and approved of the final version.

\section{REFERENCES}

ADHIKARI, K., et al. Changes in the profile of organic acids in plain set and Stirred Yogurts During Manufacture and Refrigerated Storage1. Journal of Food Quality, v.25, n.5, p.435-451. 2002. Available from: <http://onlinelibrary.wiley.com/ doi/10.1111/j.1745-4557.2002.tb01038.x/abstract>. Accessed: Feb. 22, 2018. doi: 10.1111/j.1745-4557.2002.tb01038.x.

AKALIN, A. S., et al. Viability and activity of bifidobacteria in yoghurt containing fructooligosaccharide during refrigerated storage. International Journal of Food Science \& Technology, v.39, n.6, p.613-621.2004.Available from: $<$ http://onlinelibrary.wiley.com/doi/ 10.1111/j.1365-2621.2004.00829.x/abstract>. Accessed: Feb. 22, 2018. doi: 10.1111/j.1365-2621.2004.00829.x.

AL-SHERAJI, S. H., et al. Hypocholesterolaemic effect of yoghurt containing Bifidobacterium pseudocatenulatum G4 or Bifidobacterium longum BB536. Food Chemistry, v.135, n.2, p.356-361. 2012. Available from: <http://www.ncbi.nlm. nih.gov/pubmed/22868099>. Accessed: Feb. 22, 2018. doi: 10.1016/j.foodchem.2012.04.120.

AMATAYAKUL,T.,etal.Physicalcharacteristicsofsetyoghurtmade with altered casein to whey protein ratios and EPS-producing starter cultures at 9 and $14 \%$ total solids. Food Hydrocolloids, v.20, n.2, p.314-324. 2006. Available from: <http://www.sciencedirect.com /science/article/pii/S0268005X05001050>. Accessed: Feb. 22, 2018. doi: 10.1016/j.foodhyd.2005.02.015.

AND, J. L.; M. GUO. Effects of polymerized whey proteins on consistency and water-holding properties of goat's milk yogurt. Journal of Food Science, v.71, n.1,p.C34-C38. 2006. Available from: $<$ http://onlinelibrary.wiley.com/doi/10.1111/j.1365-2621.2006. tb12385.x/abstract $>$. Accessed: Feb. 22, 2018. doi: 10.1111/j.13652621.2006.tb12385.x.

AOAC. Official methods of analysis. Washington: association of official analytical chemists. 2012

BALTHAZAR, C. F., et al. Sensory evaluation of ovine milk yoghurt with inulin addition. International Journal of Dairy Technology, v.68, n.2, p.281-290. 2015. Available from: <http:// onlinelibrary.wiley.com/doi/10.1111/1471-0307.12189/abstract> . Accessed: Feb. 22, 2018. doi: 10.1111/1471-0307.12189.

BEAL, C., et al. Combined effects of culture conditions and storage time on acidification and viscosity of stirred yogurt. Journal of Dairy Science, v.82, n.4, p.673-681. 1999. Available from: <http:// www.journalofdairyscience.org/article/S0022-0302(99)752835/abstract>. Accessed: Feb. 22, 2018. doi: 10.3168/jds.S00220302(99)75283-5.

BIROLLO, G. A., et al. Viability of lactic acid microflora in different types of yoghurt. Food Research International, v.33, n.9, p.799-805. 2000. Available from: <http://www.sciencedirect. com/science/article/pii/S0963996900001010>. Accessed: Feb. 22, 2018. doi: 10.1016/S0963-9969(00)00101-0.

BOYAZOGLU, J.; P. MORAND-FEHR. Mediterranean dairy sheep and goat products and their quality. A critical review. Small Ruminant Research: The Journal of the International Goat Association, v.40, n.1, p.1-11. 2001. Available from: $<\mathrm{http}: / / \mathrm{www}$. ncbi.nlm.nih.gov/pubmed/11259871>. Accessed: Feb. 22, 2018. doi: https://doi.org/10.1016/S0921-4488(00)00203-0

CHENG, H. Volatile flavor compounds in yogurt: a review. Critical Reviews in Food Science and Nutrition, v.50, n.10, p.938-950. 2010. Available from: $<$ http://www.ncbi.nlm.nih.gov/pubmed/21108074 $>$. Accessed: Feb. 22, 2018. doi: 10.1080/10408390903044081.

COSTA, M. P., et al. Determination of biogenic amines by highperformance liquid chromatography (HPLC-DAD) in probiotic cow's and goat's fermented milks and acceptance. Food Science \& Nutrition, v.3, n.3, p.172-178. 2015a. Available from: <https:// www.ncbi.nlm.nih.gov/pmc/articles/PMC4431784/>. Accessed: 2018/02/22/13:13:09. doi: 10.1002/fsn3.200.

COSTA, M. P., et al. Effect of different fat replacers on the physicochemical and instrumental analysis of low-fat cupuassu goat milk yogurts. The Journal of Dairy Research, v.83, n.4, p.493-496. 2016a. Available from: <http://www.ncbi.nlm.nih. gov/pubmed/27845025>. Accessed: Feb. 22, 2018. doi: 10.1017/ S0022029916000674 
COSTA, M. P., et al. Cupuassu (Theobroma grandiflorum) pulp, probiotic, and prebiotic: Influence on color, apparent viscosity, and texture of goat milk yogurts. Journal of Dairy Science, v.98, n.9, p.5995-6003. 2015b. Available from: <http://www.ncbi.nlm.nih gov/pubmed/26188580>. Accessed: Feb. 22, 2018. doi: 10.3168/ jds.2015-9738.

COSTA, M. P., et al. Consumer perception, health information, and instrumental parameters of cupuassu (Theobroma grandiflorum) goat milk yogurts. Journal of Dairy Science, v.100, n.1, p.157168. 2017. Available from: $<\mathrm{http}: / / \mathrm{www}$. sciencedirect.com/science/ article/pii/S0022030216307433>. Accessed: Feb. 22, 2018. doi: 10.3168/jds.2016-11315.

COSTA, M. P. D., et al. Simultaneous analysis of carbohydrates and organic acids by HPLC-DAD-RI for monitoring goat's milk yogurts fermentation. Talanta, v.152, p.162-170. 2016b. Available from: <http:// www.sciencedirect.com/science/article/pii/S0039914016300601>. Accessed: Feb. 22, 2018. doi: 10.1016/j.talanta.2016.01.061

DANNENBERG, F.; G. KESSLER H. Effect of denaturation of beta-lactoglobulin on texture properties of set-style nonfat yoghurt. 2. Firmness and flow properties. [English]. Milchwissenschaft. 1988. Available from: <http://agris.fao.org/agris-search/search do?recordID=DE19890125385>. Accessed: Feb. 22, 2018.

DE ANCOS, B., et al. Characteristics of stirred low-fat yoghurt as affected by high pressure. International Dairy Journal, v.10, n.1, p.105-111. 2000. Available from: <http://www.sciencedirect. com/science/article/pii/S0958694600000212>. Accessed: Feb. 22, 2018. doi: 10.1016/S0958-6946(00)00021-2.

DE RENOBALES, M., et al. Part-time grazing improves sheep milk production and its nutritional characteristics. Food Chemistry, v.130, n.1, p.90-96. 2012. Available from: <http://www.sciencedirect.com/ science/article/pii/S0308814611009496>. Accessed: Feb. 22, 2018. doi: 10.1016/j.foodchem.2011.07.002.

DIMASSI, O., et al. Cheese production potential of milk of Dahlem Cashmere goats from a rheological point of view. Small ruminant research : the journal of the International Goat Association. 2005. Available from: <http://agris.fao.org/agris-search/search. do?recordID=US201301009374 $>$. Accessed: Feb. 22, 2018. doi: https://doi.org/10.1016/j.smallrumres.2004.05.003

DOMAGAŁA, J. Sensory evaluation and rheological properties of yoghurts prepared from goat, cow and sheep milk. Electronic journal of polish agricultural universities, v.11, n.3. 2008 Available from: $<$ http://www.ejpau.media.pl/volume11/issue3/art04.html>. Accessed: Accessed: Feb. 22, 2018

DOMAGAŁA, J. Instrumental texture, syneresis and microstructure of yoghurts prepared from goat, cow and sheep milk. International Journal of Food Properties, v.12, n.3, p.605-615. 2009. Available from: <https://doi.org/10.1080/10942910801992934>. Accessed: Feb. 22, 2018. doi: 10.1080/10942910801992934.

DOMAGAŁA, J., et al. The effect of transglutaminase concentration on the texture, syneresis and microstructure of set-type goat's milk yoghurt during the storage period. Small Ruminant Research, v.112, n.1, p.154-161. 2013. Available from: $<$ http://www.sciencedirect.com/ science/article/pii/S0921448812005202>. Accessed: Feb. 22, 2018 doi: 10.1016/j.smallrumres.2012.12.003.

ERKAYA, T.; M. ŞENGÜL. A comparative study on some quality properties and mineral contents of yoghurts produced from different type of milks. Kafkas Universitesi Veteriner Fakultesi Dergisi, v.18, n.2. 2012. Available from: <http://vetdergikafkas. org/uploads/pdf/pdf_KVFD_1100.pdf $>$. Accessed: Feb. 22, 2018. doi: $10.9775 / \mathrm{kvfd} .2011 .549 \overline{8}$

FARNWORTH, E. Handbook of fermented functional food. Broken Sound Parkway, New York: CRC Press. 2008.

GHASEMPOUR, Z., et al. Optimisation of probiotic yoghurt production containing zedo gum. International Journal of Dairy Technology, v.65, n.1, p.118-125. 2012. Available from: <http://onlinelibrary.wiley. com/doi/10.1111/j.1471-0307.2011.00740.x/abstract>. Accessed: Feb. 22, 2018. doi: 10.1111/j.1471-0307.2011.00740.x.

GRANATA, L. A.; C. V. MORR. Improved acid, flavor and volatile compound production in a high protein and fiber soymilk yogurt-like product. Journal of Food Science, v.61, n.2, p.331336. 1996. Available from: <http://onlinelibrary.wiley.com/ doi/10.1111/j.1365-2621.1996.tb14188.x/abstract>. Accessed: Feb. 22, 2018. doi: 10.1111/j.1365-2621.1996.tb14188.x.

GÜLER, Z; A. C. GÜRSOY-BALCI. Evaluation of volatile compounds and free fatty acids in set types yogurts made of ewes', goats' milk and their mixture using two different commercial starter cultures during refrigerated storage. Food Chemistry, v.127, n.3, p.1065-1071. 2011. Available from: <http://www.ncbi. nlm.nih.gov/pubmed/25214097>. Accessed: Feb. 22, 2018. doi: 10.1016/j.foodchem.2011.01.090

GÜLER, Z.; H. SANAL. The essential mineral concentration of Torba yoghurts and their wheys compared with yoghurt made with cows', ewes' and goats' milks. International Journal of Food Sciences and Nutrition, v.60, n.2, p.153-164. 2009. Available from: $<$ http://www.ncbi.nlm.nih.gov/pubmed/18608571>. Accessed: Feb. 22, 2018. doi: $10.1080 / 09637480701625580$.

HARTE, F., et al. Yield stress for initial firmness determination on yogurt. Journal of Food Engineering, v.80, n.3, p.990-995. 2007. Available from: $<$ http://www.sciencedirect.com/science/article/pii/ S0260877406005188>. Accessed: Feb. 22, 2018. doi: 10.1016/j. jfoodeng.2006.06.027.

HERRERO, A. M.; T. REQUENA. The effect of supplementing goats milk with whey protein concentrate on textural properties of set-type yoghurt. International Journal of Food Science \& Technology, v.41, n.1, p.87-92. 2006. Available from: <http:// onlinelibrary.wiley.com/doi/10.1111/j.1365-2621.2005.01045.x/ abstract>. Accessed: Feb. 22, 2018. doi: 10.1111/j.13652621.2005.01045.x.

IRKIN, R.; U. VAPUR EREN. A research about viable Lactobacillus bulgaricus and Streptococcus thermophilus numbers in the market yoghurts. World Journal of Dairy \& Food Sciences, v.3, n.1, p.25-28. 2008. Available from: https://www.semanticscholar. org/paper/A-Research-about-Viable-Lactobacillus-bulgaricusin-Irkin-Eren $/ 737 \mathrm{df} 679 \mathrm{fcd} 6708 \mathrm{cbdb} 4393054 \mathrm{fb} 222530 \mathrm{debb}$ 5c2018/02/22. Accessed: Feb. 22, 2018.

JUMAH, R. Y., et al. Effect of milk source on the rheological properties of yogurt during the gelation process. International Journal of Dairy Technology, v.54,n.3, p.89-93.2001.Available from: $<$ http://onlinelibrary. wiley.com/doi/10.1046/j.1364-727x.2001.00012.x/abstract>. Accessed: Feb. 22, 2018. doi: 10.1046/j.1364-727x.2001.00012.x.

KAILASAPATHY, K. Survival of free and encapsulated probiotic bacteria and their effect on the sensory properties of yoghurt. LWT 
- Food Science and Technology, v.39, n.10, p.1221-1227. 2006. Available from: $<$ http://www.sciencedirect.com/science/article/pii/ S0023643805001660>. Accessed: Feb. 22, 2018. doi: 10.1016/j. lwt.2005.07.013.

KAMINARIDES, S., et al. Comparison of the characteristics of set type yoghurt made from ovine milk of different fat content. International Journal of Food Science \& Technology, v.42, n.9, p.1019-1028. 2007. Available from: <http://onlinelibrary.wiley. com/doi/10.1111/j.1365-2621.2006.01320.x/abstract $>$. Accessed: Feb. 22, 2018. doi: 10.1111/j.1365-2621.2006.01320.x.

KATSIARI, M. C., et al. Manufacture of yoghurt from stored frozen sheep's milk. Food Chemistry, v.77, n.4, p.413-420. 2002. Available from: $<$ http://www.sciencedirect.com/science/article/pii/ S0308814601003673>. Accessed: Feb. 22, 2018. doi: 10.1016 S0308-8146(01)00367-3.

KRASAEKOOPT, W., et al. Comparison of texture of yogurt made from conventionally treated milk and uht milk fortified with low-heat skim milk powder. Journal of Food Science, v.69, n.6, p.E276-E280. 2004. Available from: <http://onlinelibrary. wiley.com/doi/10.1111/j.1365-2621.2004.tb10998.x/abstract> Accessed: Feb. 22, 2018. doi: 10.1111/j.1365-2621.2004. tb10998.x

KRZEMINSKI, A., et al. Structural properties of stirred yoghurt as influenced by whey proteins. LWT - Food Science and Technology, v.44, n.10, p.2134-2140.2011. Available from: $<$ http:// www.sciencedirect.com/science/article/pii/S0023643811001666>. Accessed: Feb. 22, 2018. doi: 10.1016/j.lwt.2011.05.018.

KÜCÜKÇETIN, A., et al. Graininess and roughness of stirred yoghurt made with goat's, cow's or a mixture of goat's and cow's milk. Small Ruminant Research, v.96, n.2, p.173-177. 2011. Available from: <http://www.sciencedirect.com/science/article/pii/ S0921448810003226>. Accessed: Feb. 22, 2018. doi: 10.1016/j. smallrumres.2010.12.003.

LE, T. T., et al. Physical properties and microstructure of yoghurt enriched with milk fat globule membrane material. International Dairy Journal, v.21, n. 10, p.798-805. 2011. Available from: $<$ http:// www.sciencedirect.com/science/article/pii/S0958694611001166>. Accessed: Feb. 22, 2018. doi: 10.1016/j.idairyj.2011.04.015.

LEE, H., et al. Quantitative analysis of gangliosides in bovine milk and colostrum-based dairy products by ultrahigh performance liquid chromatography-tandem mass spectrometry. Journal of Agricultural and Food Chemistry, v.61, n.40, p.96899696. 2013. Available from: <http://www.ncbi.nlm.nih.gov/ pubmed/24024650>. Accessed: Feb. 22, 2018. doi: 10.1021/ jf402255g.

LEE, W.-J.; J. A. LUCEY. rheological properties, whey separation, and microstructure in set-style yogurt: effects of heating temperature and incubation temperature. Journal of Texture Studies, v.34, n.5-6, p.515-536. 2003. Available from: <http:// onlinelibrary.wiley.com/doi/10.1111/j.1745-4603.2003.tb01079.x/ abstract $>$. Accessed: Feb. 22, 2018. doi: 10.1111/j.1745-4603.2003. tb01079.x

LOURENS-HATTINGH, A.; B. C. VILJOEN. Yogurt as probiotic carrier food. International Dairy Journal, v.11, n.1, p.1-17. 2001. Available from: $<$ http://www.sciencedirect.com/science/article/pii/ S095869460100036X>. Accessed: Feb. 22, 2018. doi: 10.1016/ S0958-6946(01)00036-X.
LUCEY, J. A. Cultured dairy products: an overview of their gelation and texture properties. International Journal of Dairy Technology, v.57, n.2-3, p.77-84. 2004. Available from: <http:// onlinelibrary.wiley.com/doi/10.1111/j.1471-0307.2004.00142.x/ abstract>. Accessed: Feb. 22, 2018. doi: 10.1111/j.14710307.2004.00142.x.

MALEK, A., et al. Sensory properties and consumer acceptance of concentrated yogurt made from cow's, goat's and sheep's milk. 2001. Available from: <https://www.scienceopen.com/ document?vid=c64ddd43-0d61-426e-a 1da-1b21f9b04b2d > . Accessed: Feb. 22, 2018.

MARTÍN-DIANA, A. B., et al. Development of a fermented goat's milk containing probiotic bacteria. International Dairy Journal, v.13, n.10, p.827-833. 2003. Available from: <http:// www.sciencedirect.com/science/article/pii/S0958694603001171>. Accessed: Feb. 22, 2018. doi: 10.1016/S0958-6946(03)00117-1.

MATARAGAS, M., et al. Quantifying the spoilage and shelflife of yoghurt with fruits. Food Microbiology, v.28, n.3, p.611616. 2011. Available from: <http://www.ncbi.nlm.nih.gov/ pubmed/21356472>. Accessed: Feb. 22, 2018. doi: 10.1016/j. fm.2010.11.009.

MAYER, H. K., et al. Quantification of cow's milk percentage in dairy products - a myth? Analytical and Bioanalytical Chemistry, v.403, n.10, p.3031-3040. 2012. Available from: <http://www.ncbi. nlm.nih.gov/pubmed/22349339>. Accessed: Feb. 22, 2018. doi: 10.1007/s00216-012-5805-1.

MAYER, H. K.; G. FIECHTER. Physical and chemical characteristics of sheep and goat milk in Austria. International Dairy Journal, v.24, n.2, p.57-63. 2012. Available from: <http:// www.sciencedirect.com/science/article/pii/S0958694611002573>. Accessed: Feb. 22, 2018. doi: 10.1016/j.idairyj.2011.10.012.

MCKINLEY, M. C. The nutrition and health benefits of yoghurt. International Journal of Dairy Technology, v.58, n.1, p.1-12. 2005. Available from: <http://onlinelibrary.wiley.com/doi/10.1111/ j.1471-0307.2005.00180.x/abstract>. Accessed: Feb. 22, 2018. doi: 10.1111/j.1471-0307.2005.00180.x.

NAKTHONG, S. Effect of flour on the microstructure of goat milk yoghurt. Journal of Animal and Veterinary Advances, v.11, n.23, p.4413-4416. 2012. Available from: $<$ http://www.medwelljournals. com/abstract/?doi=javaa.2012.4413.4416>. Accessed: Feb. 22, 2018. doi: $10.3923 /$ javaa.2012.4413.4416

NGUYEN, H. T. H., et al. The effect of fermentation temperature on the microstructure, physicochemical and rheological properties of probiotic buffalo yoghurt. Food and Bioprocess Technology, v.7, n.9, p.2538-2548. 2014a. Available from: <https://link. springer.com/article/10.1007/s11947-014-1278-x>. Accessed: Feb. 22, 2018. doi: 10.1007/s11947-014-1278-x.

NGUYEN, H. T. H., et al. Homogenisation improves the microstructure, syneresis and rheological properties of buffalo yoghurt. International Dairy Journal, v.46, p.78-87. 2015. Available from: $<$ http://www.sciencedirect.com/science/article/pii/ S0958694614001654>. Accessed: Feb. 22, 2018. doi: 10.1016/j. idairyj.2014.08.003.

NGUYEN, H. T. H., et al. Microstructure and physicochemical properties of probiotic buffalo yoghurt during fermentation and storage: a comparison with bovine yoghurt. Food and Bioprocess 
Technology. 2014b. Available from: <http://agris.fao.org/agrissearch/search.do? recordID=US201400086722>. Accessed: Feb. 22, 2018. doi: 10.1007/s11947-013-1082-z.

PANDYA, A. J.; K. M. GHODKE. Goat and sheep milk products other than cheeses and yoghurt. Small Ruminant Research, v.68, n.1, p.193-206. 2007. Available from: <http://www.sciencedirect. com/science/article/pii/S0921448806002483 > . Accessed: Feb. 22, 2018. doi: 10.1016/j.smallrumres.2006.09.007.

PAPADIMITRIOU, C. G., et al. Identification of peptides in traditional and probiotic sheep milk yoghurt with angiotensin I-converting enzyme (ACE)-inhibitory activity. Food Chemistry, v.105, n.2, p.647-656. 2007. Available from: <http://www. sciencedirect.com/science/article/pii/S0308814607003810> Accessed: Feb. 22, 2018. doi: 10.1016/j.foodchem.2007.04.028.

PARK, Y. W. Rheological characteristics of goat and sheep milk. Small Ruminant Research, v.68, n.1, p.73-87. 2007. Available from: $<$ http://www.sciencedirect.com/science/article/pii/ S0921448806002562>. Accessed: Feb. 26, 2018. doi: 10.1016/j. smallrumres.2006.09.015.

PARK, Y. W., et al. Physico-chemical characteristics of goat and sheep milk. Small Ruminant Research, v.68, n.1, p.88-113. 2007. Available from: <http:/www.sciencedirect.com/science/article/pii/ S0921448806002549>. Accessed: Feb. 26, 2018. doi: 10.1016/j. smallrumres.2006.09.013.

PASEEPHOL, T., et al. Rheology and texture of set yogurt as affected by inulin addition. Journal of Texture Studies, v.39, n.6 p.617-634. 2008. Available from: <http://onlinelibrary.wiley.com/ doi/10.1111/j.1745-4603.2008.00161.x/abstract>. Accessed: Feb. 26, 2018. doi: 10.1111/j.1745-4603.2008.00161.x.

PENNA, A. L. B., et al. High hydrostatic pressure processing on microstructure of probiotic low-fat yogurt. Food Research International, v.40, n.4, p.510-519. 2007. Available from: <http:// www.sciencedirect.com/science/article/pii/S0963996907000142>. Accessed: Feb. 26, 2018. doi: 10.1016/j.foodres.2007.01.001.

PEREIRA DA COSTA, M.; C. A. CONTE-JUNIOR. Chromatographic methods for the determination of carbohydrates and organic acids in foods of animal origin. Comprehensive Reviews in Food Science and Food Safety, v.14, n.5, p.586600. 2015. Available from: <http://onlinelibrary.wiley.com/ doi/10.1111/1541-4337.12148/abstract $>$. Feb. 26, 2018. doi: $10.1111 / 1541-4337.12148$

PHADUNGATH, C. The mechanism and properties of acidcoagulated milk gels. Songklanakarin Journal of Science and Technology, v.27, p.433-448. 2005. Available from: <https://www. semanticscholar.org/paper/The-mechanism-and-properties-ofacid-coagulated-Phadungath/335dfe6e3b102a74f74c7d3eb72e17d 317dd76f2>. Accessed: Feb. 26, 2018.

POHJANHEIMO, T.; M. SANDELL. Explaining the liking for drinking yoghurt: the role of sensory quality, food choice motives, health concern and product information. International Dairy Journal, v.19, n.8, p.459-466. 2009. Available from: <http:// www.sciencedirect.com/science/article/pii/S0958694609000545>. Accessed: Feb. 26, 2018. doi: 10.1016/j.idairyj.2009.03.004

RAO, M. A.; J. A. L. D. SILVA. Role of rheological behavior in sensory assessment of foods and swallowing. in: (Ed.). Rheology of Fluid and Semisolid Foods: Springer, Boston, MA, 2007.
Role of rheological behavior in Sensory Assessment of Foods and Swallowing, p.403-426. (Food Engineering Series).

REMEUF, F., et al. Preliminary observations on the effects of milk fortification and heating on microstructure and physical properties of stirred yogurt. International Dairy Journal, v.13, n.9, p.773-782. 2003. Available from: <http://www.sciencedirect. com/science/article/pii/S095869460300092X>. Accessed: Feb. 26, 2018. doi: 10.1016/S0958-6946(03)00092-X.

SALAÜN, F., et al. Buffering capacity of dairy products International Dairy Journal, v.15, n.2, p.95-109. 2005. Available from: $<$ http://www.sciencedirect.com/science/article/pii/ S0958694604001487>. Accessed: Feb. 26, 2018. doi: 10.1016/j. idairyj.2004.06.007.

SANAL, H., et al. Profiles of non-essential trace elements in ewe and goat milk and their yoghurt, Torba yoghurt and whey. Food Additives \& Contaminants. Part B, Surveillance, v.4, n.4, p.275-281. 2011. Available from: <http://www.ncbi.nlm. nih.gov/pubmed/24786251>. Accessed: Feb. 26, 2018. doi: 10.1080/19393210.2011.617520.

SENEL, E., et al. Changes in some properties of strained (Süzme) goat's yoghurt during storage. Small Ruminant Research, v.99, n.2, p.171-177. 2011. Available from: <http://www.sciencedirect. com/science/article/pii/S0921448811001179>. Accessed: Feb. 26, 2018. doi: 10.1016/j.smallrumres.2011.03.042.

SETTACHAIMONGKON, S., et al. Influence of different proteolytic strains of Streptococcus thermophilus in co-culture with Lactobacillus delbrueckii subsp. bulgaricus on the metabolite profile of set-yoghurt. International Journal of Food Microbiology, v.177, p.29-36. 2014. Available from: $<$ http://www. ncbi.nlm.nih.gov/pubmed/24598513>. Accessed: Feb. 26, 2018. doi: 10.1016/j.ijfoodmicro.2014.02.008

SHAKEEL HANIF, M., et al. Effect of storage on rheological and sensory characteristics of cow and buffalo milk yogurt. The Pakistan Journal of Food Science, v.22, n.2, p.6170. 2012. Available from: <https://www.researchgate.net/ publication/311902254_Effect_of_storage_on_rheological_and sensory_characteristics_of_cow_and_buffalo_milk_yogurt $>$. Accessed: Feb. 26, 2018

SILVA, V. L. M., et al. Stability of polyphenols from blueberry (Vaccinium corymbosum L.) in fermented dairy beverage. Journal of Food Processing and Preservation, v.41, n.6, p.n/a-n/a. 2017. Available from: <http://onlinelibrary.wiley.com/doi/10.1111/ jfpp.13305/abstract>. Accessed: Feb. 26, 2018. doi: 10.1111/ jfpp. 13305 .

SODINI, I., et al. The relative effect of milk base, starter, and process on yogurt texture: a review. Critical Reviews in Food Science and Nutrition, v.44, n.2, p.113-137. 2004. Available from: $<$ http://www.ncbi.nlm.nih.gov/pubmed/15116758>. Accessed: Feb. 26, 2018. doi: 10.1080/10408690490424793.

TAMIME, A. Y.; R. K. ROBINSON. Tamime and Robinson's Yoghurt, Third Edition: Science and Technology. Cambridge: Woodhead Publishing. 2007. 808 p.

TAMJIDI, F., et al. Physicochemical and sensory properties of yogurt enriched with microencapsulated fish oil. Food Science and Technology International $=$ Ciencia $Y$ Tecnologia De Los Alimentos Internacional, v.18, n.4, p.381-390. 2012. Available from: 
$<$ http://www.ncbi.nlm.nih.gov/pubmed/22859650>. Accessed: Feb. 26, 2018. doi: $10.1177 / 1082013211428212$

TORMO, M.; J. M. IZCO. Alternative reversed-phase highperformance liquid chromatography method to analyse organic acids in dairy products. Journal of Chromatography A, v.1033, n.2, p.305-310. 2004. Available from: <http://www.sciencedirect. com/science/article/pii/S0021967304001311>. Accessed: Feb. 26, 2018. doi: 10.1016/j.chroma.2004.01.043.

UYSAL-PALA, C., et al. Sensory properties of drinkable yogurt made from milk of different goat breeds. Journal of Sensory Studies, v.21, n.5, p.520-533. 2006. Available from: <http://onlinelibrary. wiley.com/doi/10.1111/j.1745-459X.2006.00077.x/abstract $>$. Accessed: Feb. 26, 2018. doi: 10.1111/j.1745-459X.2006.00077.x.

VARGAS, M., et al. Physicochemical and sensory characteristics of yoghurt produced from mixtures of cows' and goats' milk. International Dairy Journal, v.18, n.12, p.1146-1152. 2008 Available from: <http://www.sciencedirect.com/science/article/pii/ S0958694608001179>. Accessed: Feb. 26, 2018. doi: 10.1016/j. idairyj.2008.06.007.

VÉNICA, C. I., et al. Organic acids profiles in lactose-hydrolyzed yogurt with different matrix composition. Dairy Science \& Technology, v.94, n.6, p.561-580. 2014. Available from: <https:// link.springer.com/article/10.1007/s13594-014-0180-7>. Accessed: Feb. 27, 2018. doi: 10.1007/s13594-014-0180-7.

VIANA, F. S., et al. Development of new probiotic yoghurt with a mixture of cow and sheep milk: effects on physicochemical, textural and sensory analysis. Small Ruminant Research, v. 149, p. 154-162. 2017. Available from: https://www.sciencedirect.com/ science/article/pii/S0921448817300366. Accessed: Feb. 28, 2019. doi: 10.1016/j.smallrumres.2017.02.013.

VIEIRA, C. P., et al. Lactococcus lactis ssp. cremoris MRS47, a potential probiotic strain isolated from kefir grains, increases cis-9,
trans-11-CLA and PUFA contents in fermented milk. Journal of Functional Foods, v.31, p.172-178. 2017. Available from: <http:// www.sciencedirect.com/science/article/pii/S1756464617300580>. Accessed: Feb. 26, 2018. doi: 10.1016/j.jff.2017.01.047.

WANG, W., et al. Consistency, microstructure and probiotic survivability of goats' milk yoghurt using polymerized whey protein as a co-thickening agent. International Dairy Journal, v.24, n.2, p.113-119. 2012. Available from: <http://www.sciencedirect.com/ science/article/pii/S0958694611002214>. Accessed: Feb. 26, 2018. doi: 10.1016/j.idairyj.2011.09.007.

WEN, Y., et al. Quality indices of the set-yoghurt prepared from bovine milk treated with horseradish peroxidase. Journal of Food Science and Technology, v.51, n.8, p.1525-1532. 2014. Available from: <http:/www.ncbi.nlm.nih.gov/pubmed/25114343> Accessed: Feb. 26, 2018. doi: 10.1007/s13197-012-0680-5.

YANG, T., et al. Effect of exopolysaccharides from lactic acid bacteria on the texture and microstructure of buffalo yoghurt. International Dairy Journal, v.34, n.2, p.252-256. 2014. Available from: $<$ http://www.sciencedirect.com/science/article/pii/ S0958694613002239>. Accessed: Feb. 26, 2018. doi: 10.1016/j. idairyj.2013.08.007.

ZHANG, J., et al. Determination of bovine lactoferrin in dairy products by ultra-high performance liquid chromatography-tandem mass spectrometry based on tryptic signature peptides employing an isotope-labeled winged peptide as internal standard. Analytica Chimica Acta, v.829, p.33-39. 2014. Available from: $<$ http://www. ncbi.nlm.nih.gov/pubmed/24856400>. Accessed: Feb. 26, 2018. doi: 10.1016/j.aca.2014.04.025.

ZUBEIR, I. E. M. E., et al. The processing properties, chemical characteristics and acceptability of yoghurt made from non bovine milks. Livestock Research for Rural Development, v.24, n.3. 2012. Available from: <http://www.lrrd.org/lrrd24/3/zube24050. htm>. Accessed: Feb. 26, 2018. 